\title{
УЛААНБААТАР ХОТЫН ШИЛЖИХ ХӨДӨЛГӨӨН БА ШИЛЖИН ИРЭГСДИЙН НИЙГМИЙН БАЙДАЛ
}

Д.Номун-Эрдэнэ

ШУА-ийн ФСЭХ-ийн эрдэм шинжилгээний ажсилтан Цахим шуудан: потипеrdene_90@yahoo.com

\begin{abstract}
Purpose of the article is to identify the reasons of migration to Ulaanbaatar from countryside of Mongolia and situation of migrants in Ulaanbaatar. Article explores impact of migration on growth of population and social status of emigrants based on statistical data and sociological survey conducted in Ulaanabaatar in 2012 by Department of Sociology of the Institute of Philosophy, Sociology and Law.
\end{abstract}

Keywords: urbanization, migration, migrant, social status

ХХ-ХІзуунытомоохонөөрчлөлтүүдийн нэг нь хотжилт билээ. Хотжилт ба түүнийг тойрсон эерэг болон сөрөг асуудлууд ганц Монголд биш дэлхийн бүхий л орнуудад тавигдаж байгаа билээ. Манай улсын хувьд хөдөөнөөс хот руу чиглэсэн шилжих хөдөлгөөнтэй. Өнөөдөр Улаанбаатар хотод Монгол улсын нийт хүн амын 47.4\% буюу бараг тэн хагас нь амьдарч байна. Хотын хүн ам ингэж өсөж байгаа шалтгаануудын нэг нь шилжих хөдөлгөөн юм. Шилжих хөдөлгөөнийг олон талаас нь судалж байгаа хэдий ч түүнд оролцож байгаа иргэдийн дасан зохицол өөрөөр хэлбэл, нийгэмд байр сууриа олж чадаж байгаа эсэх нь тодорхой бус байгаа билээ. Тиймээс энэхүү илтгэлд Улаанбаатар хотын хүн амын өсөлтөд шилжих хөдөлгөөний үзүүлж буй нөлөөг тодруулж, шилжин ирж байгаа иргэд нийгэмд эзлэх байр сууриа олж чадаж байгаа эсэхийг авч үзэх юм. Ингэхдээ Францын социологич, философич Пьер Бурдьегийн “Хүмүүн капитал”-ын онолыг баримталсан болно. Юуны өмнө “Хүмүүн капитал”-ын төрөл, онолын талаар товч авч үзье.

Пьер Бурдье капиталын томъёоллыг К.Марксын тодорхойлсноос ялгаатай байдлаар социологийн үүднээс шинээр томъёолсон.
Энэ нь, нийгмийн харилцаанд оролцогчдын зорилго нь өөрсдийн капиталуудаа нэмэгдүүлэхэд оршдог гэж үзжээ. Ингэхдээ капиталыг 4 ангилсан байдаг. Үүнд:

1. Эдийн засгийн капитал

2. Нийгмийн капитал

3. Соёлын капитал

4. Бэлгэ тэмдгийн капитал орно.

Энэхүу капиталын төрлүүд нь хоорондоо ялгаатай боловч нэг нь нөгөөгөөр нөхцөлдөж, нягт уялдаа холбоотой юм.

Эдийн засгийн капитал: Бурдьегийн хэлснээр мөнгө рүү шууд хөрвөх боломжтой бараа, бүтээгдэхүүнийг эдийн засгийн капитал гэнэ. Энэхүу капиталын төрөл нь бусдаасаа илүү өөрийн болгож, хувьчилж авахад хялбар бөгөөд бусдыг нь хувьчлах хамгийн том үндэс болдог. Нөгөө талаас нийгэм, соёл, бэлгэ тэмдгийн капиталууд нь эдийн засгийн капиталыг нийлүүлэхэд нөлөөлдөг.

Нийгмийн капитал: Энэ нь хүмүүсийн хоорондын харилцаанаас үүсдэг. Хүмүүс хоорондоо хэр зэрэг өргөн харилцаатай байна бас хэр олон бүлэгт хамаарагдаж байгаагаар тодорхойлогдно. Нийгмийн капитал нь харилцааны сүлжээ, хүрээгээр хэмжигддэг. Энэ харилцааны сүлжээ нь 
хүмүүст найдварыг бий болгож, харилцааны баталгаа болдог. Энэхүу капитал нь эдийн засаг болон соёлын капиталтай нягт холбоотой. Хүмүүстэй харилцаанд орохын тулд мөнгө болон цаг хугацаа шаардагддаг. Харин соёлын капиталын тусламжтайгаар хүмүүс ижил түвшинтэй хүмүүстэйгээ харилцах боломжтой болдог байна.

Соёльн капитал: Энэ капиталын гол зүйлс нь нэгд, боловсрол ба хэл юм. Хүн боловсрол эзэмшихэд цаг хугацаа, хөрөнгө мөнгө, эцэг эхээс уламжлагдан ирсэн соёл, хүмүүжил нөлөөлдөг байна. ЭнэхүҮ төрлийн капитал нь өөр хүнд өгч болохгүй, тухайн хүнтэй салшгүй холбоотой тул хүн өөрөө капитал болдог. Хоёрт, объектив эд зүйлс орно. Тухайлбал урлагийн бүтээлүүд, байшин, ном гэх мэт соёлыг тээн дамжуулж байгаа биет зүйлс. Гуравт, боловсролын зэрэг ордог байна.

Бэлгэ тэмдгийн капитал: Энэхүу капитал нь бусад капиталуудаа дотроо агуулдаг. Энэ бүх капиталуудын төрлүүд бие биедээ нөлөөлснөөс Үүдэн хүний нийгмийн байр суурь, нэр хүнд үүсдэг. Соёлын капиталыг эдийн засгийн капиталын өөрчилсөн нэг тал нь гэж хэлдэг. Хүмүүсийн биеэ авч явах байдал, хэл яриа, хувцаслалт зэрэг нь эдийн засгийн капиталаас хамаардаг. Үүнээс гадна нийгмийн байр суурь, найдварын баталгаа болдог. Үүгээрээ бэлгэ тэмдгийн капиталыг эдийн засгийн капитал руу шилжүүлүж болно. Өөрөөр хэлбэл үнэтэй машин, гоё хувцас зэрэг нь хүмүүсийг илүҮ итгэл хүлээхүйц болгодог. Түүнийг мөнгө болгож ашиглах боломжтой л гэсэн үг. Бэлгэ тэмдгийн капиталыг зээл авах баталгаа гэж үзэж болох юм [7].

1990 оноос хойш хүн амын шилжих хөдөлгөөн чөлөөтэй болсон. Монгол Улсын Үндсэн Хуулийн 16 дугаар зүйлийн 18-д "Улсынхаа нутаг дэвсгэрт чөлөөтэй зорчих, түр буюу байнга оршин суух газраа сонгох, гадаадад явах, оршин суух, эх орондоо буцаж ирэх эрхтэй” гэсэн заалтын дагуу иргэд шилжих хөдөлгөөнд чөлөөтэй оролцох эрх зүйн боломжийг бүрдүүлсэн. ХX зуунд шилжих хөдөлгөөнийг хязгаарладаг байсан бөгөөд орон нутгийн иргэд зөвшөөрлөөр болон түр оршин суудаг байсан.

Улаанбаатар хотод Монгол улсын нийт хүн амын 47.4\% буюу бараг тэн хагас нь амьдарч байна. Монгол улсын нийслэлийг Улаанбаатар хэмээн 1924 онд нэрлэсэн бөгөөд 1926 онд Улаанбаатар хотын хүн ам 1500 байсан байна.

ХУснэгт 1

Хүн амын тоо ба өсөлт

\begin{tabular}{|c|c|c|c|}
\hline Он & Дундаж өсөлт & Хугацааны эх дэх хүн амын тоо & $\begin{array}{c}\text { Хугацааны эцэс дэх хүн } \\
\text { амын тоо }\end{array}$ \\
\hline $1930-1940$ & 2.1 & 10.5 & 24.2 \\
\hline $1940-1950$ & 14.8 & 24.2 & 95.8 \\
\hline $1950-1960$ & 9.6 & 95.8 & 145.8 \\
\hline $1960-1970$ & 6.8 & 145.8 & 280.5 \\
\hline $1970-1980$ & 3.9 & 280.5 & 418.7 \\
\hline $1980-1990$ & 2.8 & 418.7 & 560.6 \\
\hline $1990-2000$ & 3.1 & 560.6 & 760.1 \\
\hline $2000-2010$ & 3.8 & 760.1 & 1112.3 \\
\hline $2010-2012$ & 4.4 & 1112.3 & 1287.1 \\
\hline
\end{tabular}

1940-1950 оны үед хүн амын тоо огцом өссөн нь эрдэмтдийн үздэгээр тухайн үед төрийн зүгээс хүн амаа өсгөх, төрөлтийг нэмэгдүүлэх талаар томоохон бодлогуудыг баримталж байсантай холбоотой байна. Тухайлбал, олон хүүхэд төрүүлсэн эхийг алдарт эхийн одонгоор шагнах, хүүхдүүдэд хүүхдийн мөнгө өгөх, ихэр хүүхдүүдийг улсаас халамжлах болон эх хүүхдийн эндэгдлийг бууруулах зэрэг томоохон бодлогуудыг авч хэрэгжүүлж эхэлсэнтэй холбоотой гэж үздэг. 
Энэ огцом өсөлтийн дараах жилүүдэд хүн амын өсөлт харьцангуй буурч эхэлсэн бөгөөд 1980-1990 оны хооронд 2.8 хүртлээ огцом буурсан байна. Энэхүү бууралтыг Монгол улсын эдийн засаг, улс төр, нийгмийн томоохон шилжилттэй холбон тайлбарладаг. Тухайн үед Монгол улсын эдийн засаг уналтанд орж ажилгүйдэл, ядуурал ихэссэнтэй холбоотой. Үүнээс хойш хүн амын өсөлт жигд нэмэгдэж байгаа бөгөөд 2010-2012 онд 4.4 болон өссөн байна. 2012оны мэдээгээр хотын хүн амын тоо 1.287.100 болон өссөн байна [3].

Хүн ам зүйн онол ёсоор хүн амын өсөлтийг ердийн цэвэр болон механик өсөлт гэж хуваадаг [5].

Зураг 1.ХҮн амын өөрчлөлтийг хэмжих томъёо

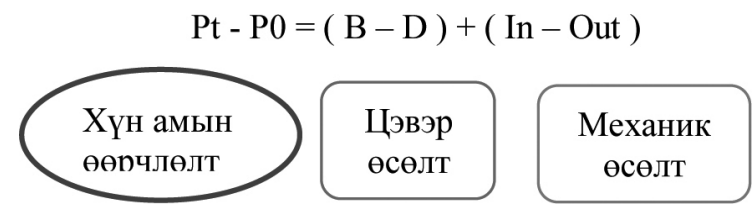

Зураг 2.ХҮн амын ичэвэр болон механик өсөлтийн коэффицчиент

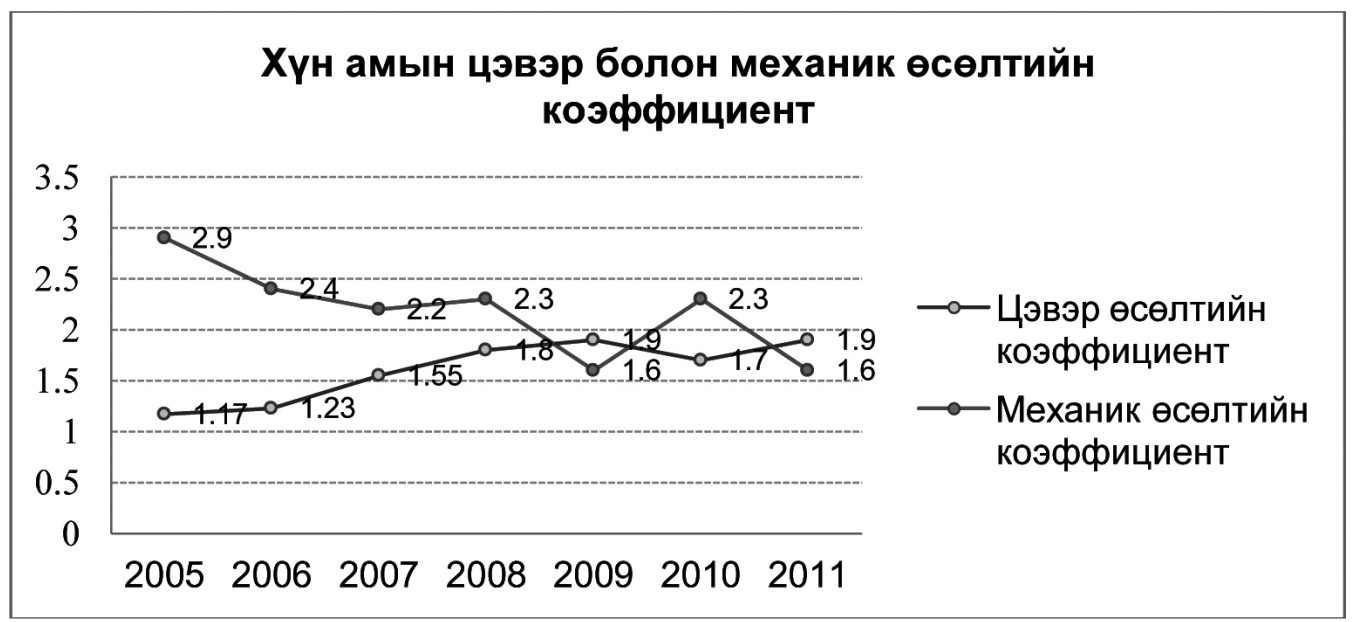

2005-2011 оны хүн амын цэвэр болон механик өсөлтийн дунджийг харахад хотын хүн амын цэвэр өсөлт 1.6 байгаа бол механик өсөлт 2.2 байна. Өөрөөр хэлбэл, механик өсөлт нь цэвэр өсөлтөөс 0.6-гаар их байна. Энэ нь хотын хүн амын өсөлтөд шилжих хөдөлгөөн тэргүүлэх нөлөөтэй байгааг харуулж байна [2].

Сүүлийн 10 жилийн статистик мэдээнээс харахад шилжих хөдөлгөөнөөс хамаарч хотын хүн ам жилд дунджаар 30000 хүнээр нэмэгдсэн байна. 
Зураг 3.СҮүлийн 30 жилийн бүсээс хамаарсан хүн амын иэвэр шилжилт

\section{Хүн амын цэвэр шилжих хөдөлгөөн /бүсээр/}

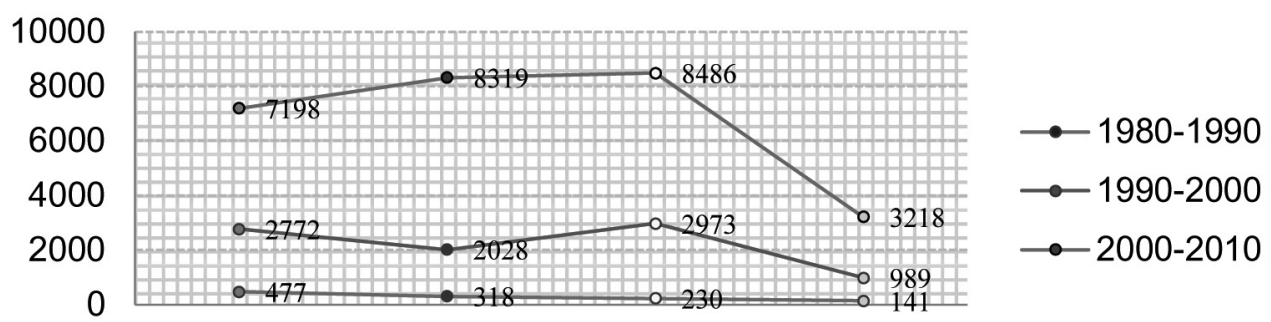

- Баруун бүө Хангайн бүс Төвийн бүс - Зүүн бүс

Зургаас харахад сүүлийн 10 жилд Улаанбаатар хотыг чиглэсэн шилжих хөдөлгөөн огцом өссөн бөгөөд өмнөх 10 жилийн дундажаас 3.1 дахин их байна. Бүсээр нь харвал Улаанбаатар хотод төвийн бүсээс шилжин ирэгсэд илүу байдаг бол зүүн бүсээс шилжин ирэгсдийн тоо харьцангуй бага байна [3].
ФСЭЗХ-ийн “Хотжих үйл явц” судалгаанд Улаанбаатар хотоос нийт 1177 респондент хамрагдсаны $62.9 \%$ нь хотын унаган иргэд (хэдэн үеэрээ хотод амьдарч байгаа, хотод төрсөн эсвэл багаасаа амьдарч байгаa), 37.1\% нь шилжин ирэгч байна.

Шилжин ирэгсдийн нас хүйсийн бүтэи

\begin{tabular}{|c|c|c|c|c|c|c|}
\hline \multirow{2}{*}{ Нас } & \multicolumn{2}{|c|}{ Нийт } & \multicolumn{2}{c|}{ Эрэгтэй } & \multicolumn{2}{c|}{ Эмэгтй } \\
\cline { 2 - 7 } & Тоо & Хувь & Тоо & Хувь & Тоо & Хувь \\
\hline $16-24$ & 99 & 23,1 & 41 & 21,9 & 58 & 24,0 \\
\hline $25-34$ & 109 & 25,4 & 42 & 22,5 & 67 & 27,7 \\
\hline $35-44$ & 79 & 18,4 & 39 & 20,9 & 40 & 16,5 \\
\hline $45-54$ & 67 & 15,6 & 29 & 15,5 & 38 & 15,7 \\
\hline $55-59$ & 36 & 8,4 & 19 & 10,2 & 17 & 7,0 \\
\hline 60 -аас дээш & 39 & 9,1 & 17 & 9,1 & 22 & 9,1 \\
\hline
\end{tabular}

Шилжих хөдөлгөөнд залуучууд(16-34 нас) $48.5 \%$ илүү оролцдог бөгөөд хижээл насныхан (35-54 нас) 34\%, ахмадуу д (55-аас дээм нас) $17.5 \%$ байна. Өөрөөр хэлбэл, Улаанбаатарыг чиглэсэн шилжих хөдөлгөөнд залуучууд тэр тусмаа залуу эмэгтэйчүүд (60\%) илүү хамрагдаж байна. Мөн нийт шилжин ирэгсдийн 56.4\% нь эмэгтэйчүүд байгаа нь жилжих хөдөлгөөнд эмэгтэйчүүд түлХүҮ оролцож байгааг харуулж байна.

2004 оны судалгаагаар Улаанбаатар хотын гэр хорооллын нийт айл өрхийн 1/3 нь шилжин ирэгсэд байдаг гэсэн судалгааны дүн байдаг [4]. Харин манай судалгаанд оролцсон нийт шилжин ирэгсдийн $65.6 \%$ нь буюу $2 / 3$ нь гэр хороололд амьдарч байна. Мөн шилжин ирэгсдийн $70 \%$ нь хотын төвд ойролцоо болон захдуу суурьшдаг байна.

Хотын төвд амьдарч байгаа нийт иргэдийн дийлэнх буюу $70.5 \%$ нь хотын унаган иргэд харин хотын захад амьдарч байгаа нийт иргэдийн олонх буюу $55.7 \%$ нь шилжин ирэгсэд байна. Энэ нь хотын төвдөө унаган иргэд түлхүү амьдарч байгаа бөгөөд хотын бүр зах руу шилжин ирэгсэд илүүтэй амьдарч байгааг харуулж байна.

Улаанбаатар хотод шилжин ирэгсдийн 
дийлэнх буюу $45.3 \%$ нь аймгийн төвөөс, $24.3 \%$ нь сум суурингаас шилжин ирдэг бол хөдөөнөөс $18 \%$ нь, хот дотроо $2.4 \%$, бусад хотуудаас $9.2 \%$ нь ирдэг байна.

Шилжин ирэх зай нь алслагдах тутам хотын төвд суурьшихаар шилжин ирэгсдийн тоо багасаж харин хотын захдуу болон бүр захад суурьшигчдын тоо өсөх хандлагтай байна. Хотод төрсөн болон хотын орчноос шилжин ирж байгаа хүмүүсийн хувьд хотын төвдөө суурьших хандлага түлхүү байна.

Зураг 4.Шилжин ирэгсдийн суурьщльн бүс ба шилжин ирсэн газар

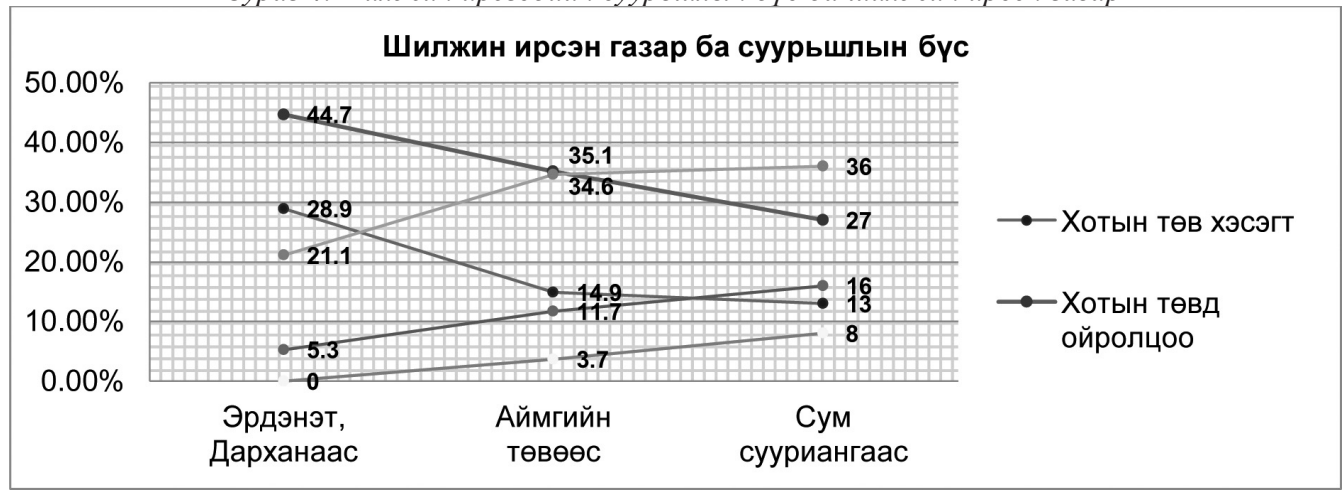

Нэг хүнд ногдох орлого, ажил эрхлэлт, сууцны нөхцлийг нь үндэслэн нийгэмд байр сууриа олсон болон хараахан байр сууриа олж чадаагүй гэсэн хоёр бүлэгт хуваан авч үзлээ.

I бүлэг -Нийгэмд эзлэх байр сууриа олж чадаагүй: Нэг хүнд ноогдох орлого нь амьжиргааны баталгаажих түвшингээс доогуур, сууцны нөхцөл нь тохилог бус, ажил эрхэлдэггүй хүмүүсийг оруулсан. Энэ бүлэгт 378 хүн буюу нийт судалгаанд оролцогчдын $38.4 \%$ нь багтсан байна.

II бүлэг -Нийгэмд эзлэх байр сууриа олсон: Нэг хүнд ноогдох орлого нь амьжиргааны баталгаажих түвшингээс дээгүүр, сууцны нөхцөл нь тохилог, ажил эрхэлдэг хүмүүсийг оруулсан. Энэ бүлэгт 680 хүн буюу 61,6\% нь багтсан байна. Хүмүүс нийгэмд байр сууриа олоход нийгэм, эдийн засаг болон бие хүний чадавхаас хамаарсан олон хүчин зүйл нөлөөлдөг.

1.Боловсролын түвшин

Зураг 5. Нийгэмд эзлэх байр сууриа олоход боловсрольвн түвшний нөлөө

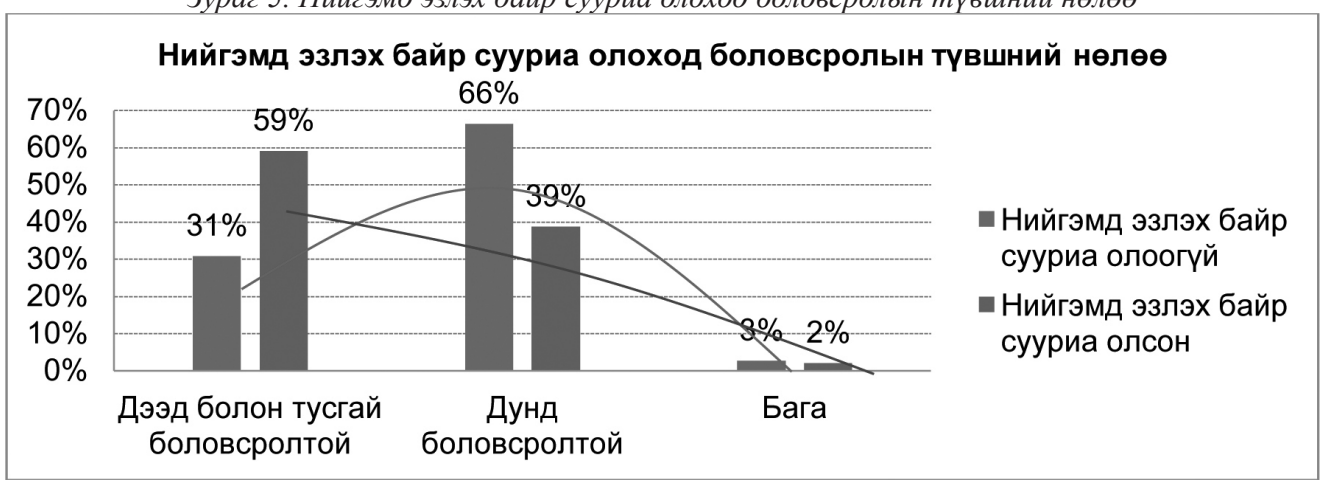

Хүмүүсийн боловсролын түвшин өсөх тусам нийгэмд эзлэх байр сууриа олох нь илүү байдаг бол боловсролын түвшин буурах тусам нийгэмд эзлэх байр сууриа олоход хүндрэлтэй байдаг байна.

1. Нийгмийн гарал 
Нийгмийн гарлын хувьд албан хаагчид $(60.7 \%)$ болон сэхээтэн (76.1\%) гаралтай хүмүүс нийгэмд эзлэх байр сууриа олсон нь өндөр хувьтай байгаа бол ажилчин болон малчин гаралтай хүмүүс харьцангуй бага хувьтай байна.

2. Нийгмийн байдал

Зураг 6. Нийгэмд эзлэх байх сууриа олоход нийгмийн байдлынн нөлөө

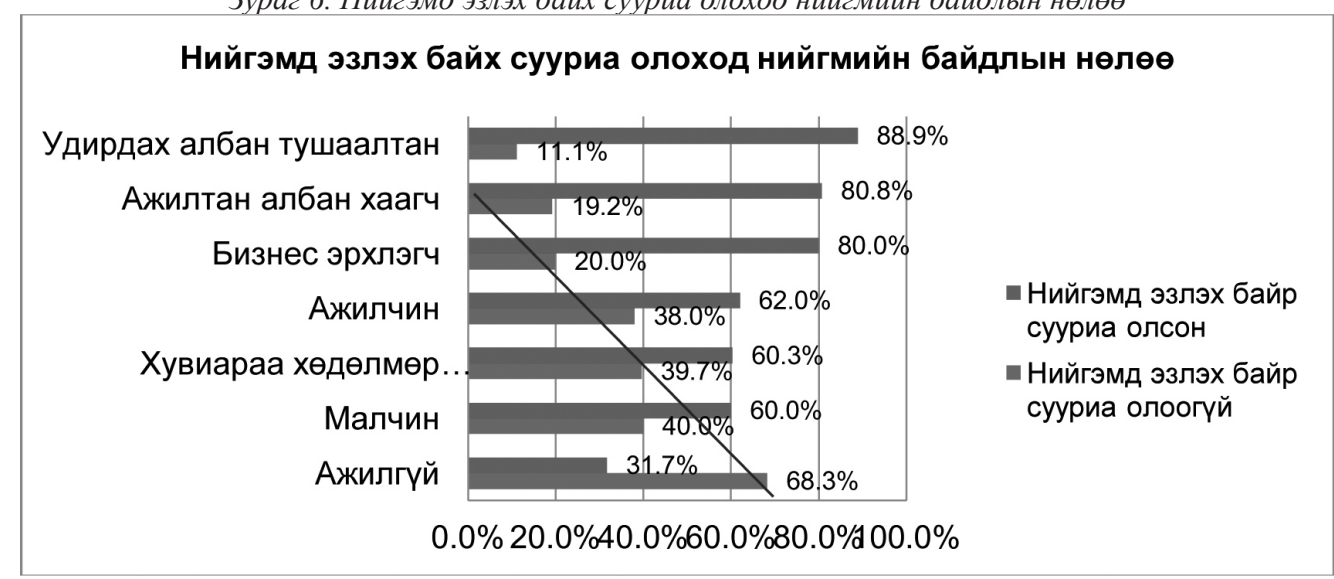

Нийгмийн байдал дээшлэх тусам нийгэмд эзлэх байр сууриа олсон нь илүү өндөр хувь эзлэж байна. Нөгөө талаас эл байдал буурах тусам нийгэмд эзлэх байр сууриа олоход бэрхшээлтэй байдаг байна. Тэр тусмаа ажилгүйчүүдийн хувьд $68.3 \%$ нь нийгэмд эзлэх байр сууриа олоогүй байгаа нь ажил бол хүний нийгмийн байр суурьт чухал нөлөөтэй байна.

3. Шилжин ирэгсдийн суурьшиж буй бүс болон нийгмийн байр сууриа олсон байдал

Зураг 7. Шилжсин ирэгсдийн суурьшиж буй бүс тэдний нийгмийн байр суурь

\begin{tabular}{|c|c|c|c|c|c|}
\hline \multirow{7}{*}{$\begin{array}{r}70.0 \% \\
60.0 \% \\
50.0 \% \\
40.0 \% \\
30.0 \% \\
20.0 \% \\
10.0 \% \\
0.0 \%\end{array}$} & \multicolumn{4}{|c|}{$\begin{array}{l}\text { Суурьшиж буй бүс болон нийгмийн } \\
\text { байр сууриа олсон байдал } \\
66.4 \%\end{array}$} & \multirow{7}{*}{$\begin{array}{l}\text { —— Нийгэмд эзлэх байр } \\
\text { сууриа олоогүй } \\
\text { ——Нийгэмд эзлэх байр } \\
\text { сууриа олсон }\end{array}$} \\
\hline & 0 & $-a$ & $56.7 \%$ & $54.5 \%$ & \\
\hline & & & $43.3 \%$ & $45.5 \%$ & \\
\hline & $33.3 \%$ & $33.6 \%$ & - & 0 & \\
\hline & 0 & -0 & & & \\
\hline & & & & & \\
\hline & Хотын төв & $\begin{array}{l}\text { Котын төвд } \\
\text { ойролцоо }\end{array}$ & $\begin{array}{c}\text { Хотын } \\
\text { захад }\end{array}$ & $\begin{array}{c}\text { Хотын бүр } \\
\text { захад }\end{array}$ & \\
\hline
\end{tabular}

Хотын төвд болон төвд ойролцоо суурьшиж байгаа шилжин ирэгсдийн хувьд өөрсдийн байр сууриа олсон нь олоогүйгээсээ 2 дахин их байна. Мөн хотын төвд болон ойролцоо суурьшсан хүмүүсийн амьжиргааны түвшин өндөр байгааг илтгэж байгаа юм. Энэ нь хотын төвд бусад хотоос ирсэн болон аймгийн төвөөс ирсэн хүмүүс түлхүү байдагтай холбоотой.

Эдгээрээс гадна хаанаас шилжин ирсэн нь нийгэмд эзлэх байраа сууриа олоход нь нөлөөтэй байна. Тухайлбал, аймгийн төвүүдээс шилжин ирсэн хүмүүсийн $64 \%$, сум суурингаас болон хөдөөнөөс 
шилжин ирсэн хүмүүсийн 56\% нь өөрийн байр сууриа олсон байна. Үүнээс харахад төвлөрсөн газруудаас шилжин ирж байгаа иргэд өөрсдийн байр сууриа олоход харьцангуй боломжтой байна.

Шинэ орчин нөхцөлд зохицохын тулд ямар нэгэн боломжийг хайж, тухайн нөхцлийг өөрчлөхөөр идэвхтэй үйл

\section{ДҮГНЭЛТ}

1. Улаанбаатар хотын хүн ам механик өсөлтөөр хурдацтай өсөж байна.

2. Шилжин ирэгсдийн гол асуудал бол хотод байр сууриа олох байдаг. Өөрөөр хэлбэл, шилжин ирэгчдэд ажилд орох, амьдралаа залгуулах, амьдрах орон байр чухлаар тавигдаж эхэлдэг. Улаанбаатар хотод нийт шилжин ирэгсдийн 38,4 хувь нь амьдрах байр сууриа олоогүй хүмүүс байна.

3. Хотын дасан зохицож амьдрахын тулд идэвхтэй үйл ажиллагаа явуулж байгаа хүмүүс илүү байр сууриа олсон байдаг нь харагдаж байна. Шилжин ирээд суурьшсан жил нь ихсэх тутам хүмүүсийн дасан зохицож амьдрах чадвар нь өсдөг байна. Судалгааны дүнгээс харахад шилжин ирээд нэг жил болоогүй хүмүүс 100\% нийгэмд эзлэх байр сууриа олж чадаагүй байдаг байна. Харин нэг жил амьдарсан хүмүүсийн 60 орчим хувь нь байр сууриа олчихсон байдаг. Үүнээс дүгнэвэл шилжин ирэгсдийн хувьд хамгийн багадаа нэг жилийн дараа л нийгэмд эзлэх байр сууриа олж эхэлдэг байна. Өөрөөр хэлбэл шилжин ирж байгаа хүмүүс хотын орчинд дасан зохицож эхлэхэд хамгийн багадаа шаардагдах хугацаа нь нэг жил байдаг байна. ажиллагаа явуулж байгаа хүмүүс байр сууриа олох нь харьцангуй өндөр байна.

Мөн шилжин ирээд суурьшсан хугацаа нь бага боловч нөлөөтэй байна. Тухайлбал, шилжин ирээд 36-56 жил болсон хүмүүсийнхээс 4-өөс доош жил болж байгаа хүмүүсийн байр сууриа олсон байдал ойролцоогоор 13\%-иар бага байна.

4. Пьер Бурдьегийн "Хүмүүн капитал”ын онол ёсоор соёлын капиталыг дээшлүүлснээр эдийн засгийн капитал болон бусад капиталыг дээшлүүлэх боломжтой байдаг. Хүмүүсийн нийгэмд эзлэх байр сууриа хараахан олж чадахгүй яваа нь нийгэм, эдийн засаг, хувь хүний чадавхтай холбоотой нэлээд хэдэн хүчин зүйлээс шалтгаалдаг. Тухайлбал:

Боловсролын түвшин өндөр, сэхээтэн гаралтай, удирдах түвшний албан тушаалтай хүмүүс илүҮ нийгэмд эзлэх байр сууриа олж чаддаг байна. Тийм хүмүүсийн хувьд ажил эрхэлдэг, амьжиргааны баталгаажих түвшингээс дээгүүр орлоготой, тохилог сууцанд амьдардаг байна. Харин боловсролын түвшин бага, малчин болон ажилчин гаралтай, ажил эрхэлдэггүй хүмүүсийн хувьд нийгэмд эзлэх байр сууриа олоход хүндрэлтэйбайхбөгөөдамьжиргааны баталгаажих түвшингээс доогуур орлоготой, тохилог бус сууцанд амьдардаг байна. Соёлын капиталаа хараахан бүрдүүлж чадаагүй хүмүүс эдийн засгийн болон нийгмийн капиталаа дээшлүүлж чадахгүй байгаа нь харагдна. 


\section{Аиигласан бүтээлийн жагсаалт}

1. Монгол Улсын үндсэн хууль. Монгол Улсын хуулийн эмхэтгэл I боть. УБ.,2008

2. Монгол улсын статистикийн эмхтгэл. Монгол Улсын Үндэсний статистикийн хороо. УБ.,2005-2011

3. Улаанбаатар хотын статистикийн мэдээ. Улаанбаатар хотын статистикийн газар. УБ.,2012.

4. Монголын хүн амын сэтгүүл. 2004. №11

5. Хүн ам зүйн үндсэн асуудлууд. /сурах бичиг/ ХАССТ. УБ.,2006

6. http://zugeistreich.wordpress.com/kapitalbegriffe/. 2013.07.21 